\title{
DEVELOPMENT OF CONSTRUCTION INVESTMENT IN THE RURAL AREA
}

\author{
Iryna Azhaman', Nataliya Petryshchenko²
}

\begin{abstract}
The research purpose is to formulate proposals for investment development in the construction of industrial and civilian objects in the countryside of Ukraine, taking into account the experience of rural area development in the EU. Theoretical and methodological basis of the research is the dialectical method of cognition of socio-economic phenomena in their interconnection, basic provisions of economic theory, scientific developments of domestic and foreign scientists on investment development in rural area construction. The following methods were used in the work: theoretical synthesis, analysis and synthesis, historical, abstract-logical method, dialectic in the study of theoretical foundations of the problem under study and in the formulation of conclusions and proposals. The subject of the study is a set of theoretical, methodological, and applied provisions in the field of investment development in construction in rural areas of Ukraine. Practical implications. When investing in countryside construction development, it is proposed to adhere to the following principles: investor's free choice of directions and investment volumes; voluntary investment; purposefulness of investments; transparency of the process of using investments in the implementation of construction projects; informative value; independence and responsibility. Taking into account main directions of village social sphere development defined by the state and the current state of investing in rural area civil construction, it is proposed to increase the rights and responsibilities of local authorities and self-government. In order to intensify housing construction in the countryside, individual developers and business entities are encouraged to create mutual funds for financing construction and housing in rural areas. It has been established that during the period of research, investing in industrial and civil construction is distinguished by unevenness and is marked by a significant dependence on the general state of the country's economy. To enhance investment in industrial and civil construction in the countryside as a factor of increasing socio-economic and environmental impact of the agrarian sector, it is advisable to use different sources of capital investment and increase their number. An attractive investment environment for industrial and civil construction in the countryside is formed at the expense of: the sustainable economy and society development; encouragement of entrepreneurial activity of the population; encouraging enterprises and organizations to carry out expanded reproduction; competent banking and financial and credit policy of the state and local self-government bodies.
\end{abstract}

Key words: investments, rural area, world experience, development programs, grants, investment sources, industrial construction, civil construction.

JEL Classification: G11, R11, R33

\section{Introduction}

Rural area development involves the balanced construction of facilities for industrial, residential, and infrastructure-serving purposes. This requires the formation of an effective mechanism for attracting, distributing, and using investment funds. After all, the financial component largely determines the reality, volume, structure, timing, and quality of construction project implementation.
The complexity of investment in the construction is caused by the fact that construction of industrial and civilian objects requires a long period of time. Volumes of investments depend on the scale and methods of construction and installation work, modern construction technologies and materials use level, which ultimately significantly influences the cost of construction. Construction of agricultural sector objects may be delayed due to various reasons, which

\footnotetext{
Corresponding author:

${ }^{1}$ Odessa State Academy of Civil Engineering and Architecture, Ukraine.

E-mail:ag irisya@ukr.net

ORCID: https://orcid.org/0000-0002-0245-1652

${ }^{2}$ Odessa State Academy of Civil Engineering and Architecture, Ukraine.

E-mail: diadema@ukr.net

ORCID: https://orcid.org/0000-0001-9172-9304
} 
is reflected in costs that are formed by periods in actual prices. The choice of object construction method affects its terms and, accordingly, the schemes and terms of investment. Intensification of investment in the construction of industrial and civilian objects in a rural area will contribute to the comprehensive development of regions and the country as a whole.

Issues of investment development in industrial and civil construction were analysed in scientific works of leading domestic researchers. Thus O. V. Vasiliev (2010) defines modern forms of investment in housing construction. Y. M. Safonov and V. G. Yevteyeva (2013) consider attracting mechanisms and financing sources for investment in construction. In the works of A. I. Rybak and I.B. Azarova, results of the study of construction project financing mechanisms in the field of construction, as well as market financing mechanisms (2014), are presented. R. Kamiński, Chuan Chen, Yibin Ao, Yan Wang, Jiayue $\mathrm{Li}$ consider investment in social infrastructure in rural areas $(2017,2018)$. $\mathrm{D}$. Yongheng and $\mathrm{W}$. Jing researched investing in green building (2014). However, the results of research do not adequately cover peculiarities and perspective directions of investment development in countryside construction.

Based on the above, the research purpose is to formulate proposals for investment development in the construction of industrial and civilian objects in the countryside of Ukraine, taking into account the experience of rural area development in the EU.

Theoretical and methodological basis of the research is the dialectical method of cognition of socio-economic phenomena in their interconnection, basic provisions of economic theory, scientific developments of domestic and foreign scientists on investment development in the rural area construction. The following methods were used in the work: theoretical synthesis, analysis and synthesis, historical, abstract-logical method, dialectic - in the study of theoretical foundations of the problem under study and in the formulation of conclusions and proposals.

The main objectives of the study were: to work out the theoretical foundations of the development of investment in construction in rural areas, in particular, to determine the essence and main classification criteria for investing in construction in the countryside; to explore the world practice of promoting rural development and construction; to explore the domestic practice of investing in construction in rural areas; to formulate proposals for the further development of investment in construction in the countryside of Ukraine, which can also be used in the practice of other countries.

\section{Essence and main classification criteria for investing in construction in rural areas}

Financing of construction in rural areas reflects investment in tangible assets. According to a classification given in the Order of State Statistics Service of Ukraine, their list of construction activities includes investments in existing buildings and structures, residential buildings, non-residential buildings, structures. Taking into account the variety of types of construction objects and forms of construction activity (new construction, reconstruction, etc.), the following classification of investments in construction development in rural areas is proposed (Order of the State Statistics Committee of Ukraine, 2009; Azhaman, 2014):

- investments in reconstruction, modernization of existing objects of residential, socio-cultural, industrial, engineering, and other purposes with the goal of ensuring their compliance with modern requirements of users. The need for such investments is conditioned by the objective need to rehabilitate existing facilities in order to reduce their energy, water consumption, maintenance and service costs, greater convenience of use, etc. This type of investment is also proposed to include investment in overhaul, as well as maintenance; - investments in the construction of residential properties - include investments in the construction of residential buildings in rural areas. Such investment may be directed to the implementation of construction projects for both construction of new objects and objects of incomplete construction;

- investments in the construction of production, service and auxiliary facilities - provide for the construction of facilities that will be used in the process of the economic activity. These may be facilities that belong to both legal entities and individuals;

- investing in objects of socio-cultural, medical-health, educational purposes;

- investment in objects of engineering and technical purposes, in particular, construction of highways, power lines, gas and water pipelines, etc.;

- investing in other buildings.

The specified types of investments are different in terms of volumes, their development, sources of attraction, the ultimate effect of use, and provide for the satisfaction of individual needs of individuals, rural businesses, rural communities, etc.

Investing in countryside construction is defined as a process of investing property and intellectual property in the development of building construction in rural areas (Azhaman, 2014). It has a long-term character and a certain purpose. The general objective of investing in construction development in rural areas is to obtain an effect - economic, social, and environmental or a combination of them. The economic effect of investing is possible from investing in construction projects for the construction of facilities for production, auxiliary, and serving purposes. Also, this effect can be obtained by constructing and reconstructing engineering and technical objects, in particular, roads - decreasing product losses during transportation, reducing product delivery time to consumers; reclamation systems increase and guarantee yields of agricultural crops, etc. 
Construction of social and cultural objects, education, and health will provide a long-term social impact. The ecological effect is determined by the use of natural materials, resource-saving (energy, water-saving) technologies, which reduce the negative impact on the environment, construction of modern treatment systems, etc. However, investing in construction projects that involve the use of modern building technologies and the use of advanced materials can provide a comprehensive effect.

Entrepreneurial construction of residential buildings in the countryside has a social effect - living conditions of inhabitants are improving, an economic one it is an integral part of employees' motivation system, and ecological - on condition of observance of technologies and requirements of sanitary-hygienic, ecological, architectural norms reduces the negative impact on the environment. In addition, investing in construction solves the problem of ensuring even countryside development.

Objects of investment activity are projects for construction of facilities for production, auxiliary and service, socio-cultural, medical and recreational, educational and other purposes, as well as residential buildings. According to the current legislation, it is prohibited to devote money, i.e. to invest, only in objects, the creation and use of which do not meet the requirements of sanitary, radiation, environmental, architectural, and other norms provided by the legislation of Ukraine, and also violate the rights and interests of citizens, legal entities, and state protected by law. Investments in countryside construction development may be money, property and property rights, and others.

\section{World practice of promoting rural development and construction}

In the world practice, different approaches to the socio-economic development of rural areas and, in particular, construction, have been formed. Thus, according to the European Information and Research Center studies, the European Rural Development Policy aims at helping the EU's rural areas address economic, social, and environmental issues. This assistance is funded by the European Agricultural Fund for Rural Development (EAFRD), which has allocated $€ 99.6$ billion for 2014-2020. EU countries have developed rural development programs Table 1.

Note that all these programs are developed at the state level and are financed at the expense of funds: the EU, the European Agricultural Fund for Rural Development, and national budgets.

Table 1

Analysis of rural development programs of EU countries for 2014-2020

\begin{tabular}{|c|c|c|}
\hline Country & Program & Main directions of financing \\
\hline $\begin{array}{l}\text { Kingdom } \\
\text { of Belgium }\end{array}$ & $\begin{array}{l}\text { Flanders Rural Development Program } \\
\text { Walloon Rural Development Program }\end{array}$ & $\begin{array}{l}\text { Preservation of environment } \\
\text { Increasing rural sector competitiveness } \\
\text { Support for young farmers } \\
\text { Improving the quality and viability of rural areas }\end{array}$ \\
\hline Bulgaria & $\begin{array}{l}\text { National Rural Area Development } \\
\text { Program }\end{array}$ & $\begin{array}{l}\text { Increasing competitiveness and balanced development of the country's } \\
\text { agriculture and forestry } \\
\text { Guard and balanced management of ecosystems } \\
\text { Socio-economic development of rural areas }\end{array}$ \\
\hline Hungary & $\begin{array}{l}\text { National Rural Area Development } \\
\text { Program }\end{array}$ & $\begin{array}{l}\text { Restoration, conservation and strengthening of ecosystems } \\
\text { Promoting social inclusion, poverty reduction, and rural economic development } \\
\text { Modernization and competitiveness of farm enterprises }\end{array}$ \\
\hline Slovak Republic & $\begin{array}{l}\text { National Rural Area Development } \\
\text { Program }\end{array}$ & $\begin{array}{l}\text { Increasing agriculture and forestry competitiveness through investments } \\
\text { Protection and support of biodiversity, soil, water resources } \\
\text { Improving the economic and social conditions of the rural population by } \\
\text { investing in a new infrastructure network, creating new jobs }\end{array}$ \\
\hline Romania & $\begin{array}{l}\text { National Rural Area Development } \\
\text { Program }\end{array}$ & $\begin{array}{l}\text { Increasing competitiveness and restructuring the agricultural sector. } \\
\text { Environmental protection and climate change } \\
\text { Economic development, creating new jobs and improving life quality in } \\
\text { Romanian villages }\end{array}$ \\
\hline $\begin{array}{l}\text { Federal Republic } \\
\text { of Germany }\end{array}$ & $\begin{array}{l}13 \text { regional rural development } \\
\text { programs, of which } 2 \text { are common to } \\
\text { all regions }\end{array}$ & $\begin{array}{l}\text { Promoting agriculture, forestry, and food industry competitiveness } \\
\text { Ensuring Sustainable Management of Natural Resources and Climate Protection } \\
\text { Balanced territorial development of agriculture and rural areas. }\end{array}$ \\
\hline $\begin{array}{l}\text { Republic } \\
\text { of Poland }\end{array}$ & $\begin{array}{l}\text { National Rural Area Development } \\
\text { Program }\end{array}$ & $\begin{array}{l}\text { Development of farms } \\
\text { Investing in knowledge and innovation, agricultural advisory } \\
\text { Balanced management of natural resources } \\
\text { Creation of new jobs, improvement of living conditions in rural areas, balanced } \\
\text { territorial development of rural areas }\end{array}$ \\
\hline
\end{tabular}




\section{The experience of Ukraine in investing in construction in the countryside}

Taking into account that investment in construction development in the countryside of regions of Ukraine is an integral part of total construction investment, it is expedient to analyse sources of investment in capital investments for 2009-2015. Researches show their growth by $41.6 \%$, including at the expense of: funds from local budgets, own funds of enterprises and organizations, as well as public funds for housing construction. During 2009-2015, the volume of investments at the expense of own funds of enterprises increased by $44 \%$, and funds of local budgets by 2.4 times.

The growth of private investment weight is also noted in the report on Investment Policy in Agriculture: Ukraine (Website of the Embassy of Japan in Ukraine) project results. The report states that investment in recent years is mostly private. So, under the condition that most grain storage facilities are state-owned (owned by the State Food and Corn Corporation of Ukraine, etc.) in 2014-2015, warehouse capacities were built by foreign companies Archer Daniels Midland Co., Cargill, and Louis Dreyfus Commodities Group. Among domestic companies, the activity of Agribusiness Nibulon, which invested in storage facilities in ports, was marked.

Capital investment is carried out in tangible and intangible assets. The total amount of investments for 2009-2015 has increased by $41.6 \%$, including the increase by 36.2 , in tangible assets and by 3.1 times in intangible ones. The share of investments in tangible assets in 2015 was $93.3 \%$. Investments in tangible assets are injected in residential, non-residential buildings and structures, machinery and equipment, vehicles, etc.

Summarizing the study of capital investment directions, the leading place of investment in tangible assets, in particular, non-residential buildings and structures, as well as development of housing construction, has been identified. Such tendencies are characteristic for the country as a whole and can also be observed for the countryside. Accordingly, there are grounds to assert intensification of housing construction at the expense of population and industrial sector mainly for own funds of enterprises and organizations, whose share tends to increase.

When investing in the countryside construction development, it is proposed to adhere to the following principles: investor's free choice of directions and investment volumes; voluntary investment; purposefulness of investments; transparency of the process of using investments in the implementation of construction projects; informative value; independence and responsibility.

The country regulatory framework in force defines main provisions for investment activities. However, taking into account the diversity of construction activities, in which there is a need for rural development, it is necessary to identify features and mechanisms for investing in such key areas as housing objects construction; construction of social sphere objects; construction of production purpose objects and those that create conditions for the efficient production and commercial activities of economic entities.

Investments in housing construction are carried out through construction financing funds, real estate funds, joint investment institutions, as well as by issuing targeted bonds, fulfilling obligations that are secured by the unit of such real estate, in accordance with the legislation. However, such a form of investment is inappropriate in rural areas, as housing construction is carried out mainly from own or borrowed funds of individual developers or at the expense of village business entities who are interested in decent working conditions for their employees.

The following benefits are provided for individual housing construction within villages and settlements, as well as outside them in isolated farmsteads: provision of preferential terms for building materials and equipment provision; provision of concessional longterm government loans; compensation of $25 \%$ of the preferential long-term state credit amount to developers in 5 years after introduction of buildings into operation, provided that they constantly work in agricultural production, processing and serving industries of agriculture, are located in rural areas, social sphere of the village, and local village self-government bodies; individual developers who did not use privileged state loans are given an opportunity to receive compensation in the amount of $35 \%$ of the built constructions and structures cost.

It should be noted that the implementation of such measures to promote the development of village housing construction is hampered by limited budget funds, which in practice prevents the provision of privileges and compensations to rural individual developers. Thus, in the State Budget of Ukraine from 2011, a negative trend has emerged regarding the state preferential lending to individual rural developers for construction (reconstruction) and purchase of housing. In relative terms, the share of government privilege in general budget expenditures decreased from 0.0175 to $0.0065 \%$.

Stimulation of village housing construction at the regional level was realized by the Odesa Regional Council through the adopted decision "On Approval of a Regional Program to Support Individual Village Housing Construction 'Own Home' for 2012-2016." Such a program also operated in Odesa region earlier in the period of 2006-2010. Long-term preferential loans to individual rural developers in the amount of 21.1 million UAH were provided, including social workers - 1.7; agroindustrial complex - 10.9 million $\mathrm{UAH}$. To implement the program, funds were sent 
from the state and local budgets, bank loans, voluntary contributions from legal entities and individuals. The program was aimed at ensuring affordability of housing, increasing its construction, improving living conditions in rural areas. During 2011-2015, expenditures on construction development in the country have been reduced.

Implementation of measures to promote countryside housing construction development is also hampered by the complexity of the process of collecting and submitting documentation for benefits and compensations for housing construction in rural areas (Website: Territorial Cooperation of the Eastern Partnership Countries).

Investing in countryside social objects has a number of features, among which the main ones should be highlighted:

- as a result of such investments, mainly a social effect is received, and therefore, most potential private investors (rural residents, rural businesses) are not interested in such investments because of the lack of personal income or long payback periods;

- the village social sphere is low-liquid;

- construction of social and cultural objects, in particular, clubs, stadiums, health facilities and the like, is largely characterized by long terms of project implementation and their high cost, which is connected not only to the need to build objects but also to their installation and putting into operation;

- state funding for the construction development of social facilities in rural areas is limited and decreases annually. Thus, the State Budget of Ukraine for 20112015 provided for expenditures, the amount of which varied from 7761.5 thousand UAH in 2011 to 1785 thousand UAH in 2014, in the future, expenditures from the state budget for reforming communal services in rural areas of Ukraine were not foreseen.

Such features of investment activity in the countryside social sphere explain insignificant volumes of construction and putting into operation of such objects. However, along with this, there are a number of regulatory acts in the state that are aimed at developing the construction of social facilities in the rural area. Thus, in the Law of Ukraine "On Priority of Village and Agro-Industrial Complex Social Development in the National Economy," the priority of village social development is provided, among other things, by the state through a series of organizational, economic, and legal measures.

Construction of socio-cultural sphere objects and facilities of engineering and technical purposes in rural areas is carried out at the expense of state and local budgets. Of great importance is the issue of social protection of rural residents. In particular, it is noted that peasants are given preference over city residents for assistance in the construction of housing, social services, and cultural services.

\section{Proposals for the further development of investment in the construction of industrial and civilian objects in rural areas}

Taking into account main directions of village social sphere development, defined by the state, and the current state of investing in civil construction in rural areas, it is proposed to increase rights and responsibilities of local authorities and self-government. The latter providesfor the right to determine priority directions for the development of construction of countryside social facilities, fund allocation for implementation of such projects, control over their use and quality of work performance. For this, it is proposed to leave at the disposal of local budgets up to 3 (but not less than 1) percent of the regional gross domestic product value for the development of construction and strengthening of material and technical base of the village social sphere. The final funding percentage for the development of construction of rural area social facilities will be determined by local authorities, taking into account the state of population provision with such objects, the dynamics of funds receipt by the local budget, and the level of social protection of peasants in a certain rural territory.

Thus, decentralization in the field of financing village construction development will make it possible first of all to implement priority social construction projects for this area and increase the interdependence level between the amount of financial revenues from economic activity in the region and the state of social provision of its inhabitants.

According to the said, the main sources of development investment in the village social sphere construction will be as follows:

- deductions from local budgets for the realization of programs and projects of village social sphere development;

- investments of business entities in the countryside;

- funds of organizations, associations, societies and other unions of legal entities and individuals interested in countryside social sphere development;

- investments from other sources that do not contradict current legislation.

Another direction of investment development of village construction is an investment in new construction, reconstruction of industrial facilities, in particular production, service, and auxiliary purposes.

Investments in construction development of rural area production facilities are carried out in accordance with the Laws of Ukraine: "On Investment Activity," "On Priority of Village and Agro-Industrial Complex Social Development in the National Economy," "On State Support of Agriculture in Ukraine," etc.

The State Budget of Ukraine analysis has shown that in the part of expenditures, a separate line does not allocate funds for the construction development of rural area production facilities. However, there are a number 
of support programs for the development of the crop, livestock, and formation of a network of wholesale markets. Such programs can potentially be considered as a source of funding for the construction of industrial objects necessary for their realization in the village. However, in 2015 , funding in this direction has not been carried out.

In 2011, 10 million UAH was allocated in the state budget for the creation of a network of wholesale markets, and in $2012-200$ million UAH. In subsequent years, funding for this item of expenditure was not carried out. Such amounts of state support do not correspond to those specified in the Cabinet of Ministers of Ukraine Decree "On Approval of the State Target Program for Establishment of Wholesale Markets of Agricultural Products," which stipulated sources and amounts of financing.

Construction of production facilities for the agrarian sector is carried out using the following sources: own or attracted funds of agricultural enterprises, financing of state and local budgets under programs of support of plant growing, livestock breeding, other sources which do not contradict current legislation.

According to survey results, the total value of agriculture investments amounted to $6.5-10.7 \%$ of the total amount of the national economy's capital investments. State budget investments are not the main source of capital investment financing. Thus, in the structure of agriculture investments, the state share accounted for $2.3 \%$ of their total amount. At the same time, the capital investment share has a steady tendency to decrease - in $2015-0.1 \%$. Consequently, in the current normative-legal field, basic principles and approaches to the countryside industrial construction development have been formed. However, the procedure is not clearly defined and the peculiarities of investment in construction development of such objects are not taken into account.

Prospects for increasing crop and livestock production rate, among other things, are determined by the state financial policy in support of agricultural producers. Such support is targeted.

Taking into account the state of investing in rural construction development and state support dynamics, it is proposed to focus on finding ways to attract investment from such sources: own resources of rural residents, countryside business entities; funds of unions, associations, societies, public and religious organizations; funds of legal entities interested in countryside construction development of the region; funds of state and local programs for the promotion of rural development, intended for housing, social-cultural and other types of construction; cash back and other investment funds; bank loans; foreign investments in the form of "donor assistance" for the development of rural areas, industrial sector, etc.; international technical assistance; other sources of investment in development of countryside industrial and civil construction. To do this, it is suggested to use the following levers:
- tax - a reduction of the tax burden for village economic entities that carry out the construction of industrial and civilian facilities with their own or attracted funds;

- information - familiarization of rural area business entities with existing programs supporting construction development of countryside industrial objects; conducting seminars and consultations on the use of modern approaches of enterprise employee motivation and stimulation on the basis of construction development of socio-cultural and residential objects; - marketing - use of social advertising and other marketing tools to create a positive image of the countryside as an attractive place of employment and residence;

- political and legal - strengthening activities of state and local authorities in the direction of ensuring social protection of rural population and supporting priority sector of the country's economy - the agrarian sector.

In order to stimulate the development of rural areas and, in particular, construction in the countryside, it is proposed to invest in such activities with the assistance of grants. There are a number of programs and funds in Ukraine that finance development of the state, its regions, individual economic entities. The list of proposed programs (funds) is presented in Table 2.

From the above-mentioned funds and programs list for the development of village socio-cultural objects construction, including hospitals, health centres, educational establishments, cultural and sports institutions are invited to participate in regional grants competitions for: "Kusanone" Program (Japan), projects of the U.S. Ambassadors Fund for Cultural Preservation and International Renaissance Foundation and others. The possibility of obtaining such grants is confirmed by the example of Biliaivka united community of the Odesa region, which received a grant from the International Renaissance Foundation for the "Biliaivka United Community Integrated Development" project, which carried out: an analysis of the resource base of Biliaivka united community development, drafting of Community Passport, development and lobbying of long-term community development strategies, community social and economic development plan for 2016-2017.

Under this initiative, funding was received in the amount of 330 thousand UAH. Grant aid for investing in rural development may be involved at both regional and individual community levels. Thus, the U.S. Ambassadors Fund for Cultural Preservation is simultaneously implementing the Small Grants Program and the Large Grants Program.

It is proposed to pay attention to the possibility of financing projects involving funds from the Monsanto Foundation, the Eastern Partnership Territorial Cooperation (EaPTC), the European Bank for Reconstruction and Development (EBRD), the Ukraine-Habitat Fund, etc., for development of rural area industrial facilities construction in Ukraine. 
Vol. 5, No. 2, 2019

Table 2

Proposals for funds and programs providing grants for construction development in the countryside of Ukraine

\begin{tabular}{|c|c|c|}
\hline Fund/Program & Direction & Description \\
\hline "Kusanone” Program (Japan) & $\begin{array}{l}\text { Assistance in development } \\
\text { project implementation }\end{array}$ & $\begin{array}{l}\text { Has been operating in Ukraine since 2002. Financial assistance to non- } \\
\text { governmental organizations, hospitals, primary schools, research institutes, } \\
\text { and other non-profit organizations to implement development projects. }\end{array}$ \\
\hline \multirow[b]{2}{*}{$\begin{array}{l}\text { US Embassy's Fund for Cultural } \\
\text { Heritage Preservation }\end{array}$} & Small Grants Program & $\begin{array}{l}\text { Preservation of cultural monuments, museum collections, and } \\
\text { traditional art forms. }\end{array}$ \\
\hline & The Great Project & $\begin{array}{l}\text { Preservation of prominent archaeological sites, historic buildings, } \\
\text { monuments and museum collections of exceptional value as an } \\
\text { inheritance of a country or a region. }\end{array}$ \\
\hline $\begin{array}{l}\text { International Renaissance } \\
\text { Foundation }\end{array}$ & $\begin{array}{l}\text { Support of public initiative } \\
\text { implementation }\end{array}$ & $\begin{array}{l}\text { Founded in 1990. Funding and organizational support for the } \\
\text { establishment of a democratic, open society in Ukraine by supporting } \\
\text { initiatives important for its development. }\end{array}$ \\
\hline \multirow{2}{*}{ Monsanto Foundation } & $\begin{array}{l}\text { Small Business Development } \\
\text { Project in Rural Communities } \\
\text { of Ukraine }\end{array}$ & $\begin{array}{l}\text { Enhancing entrepreneurial and leadership potential among rural } \\
\text { communities. }\end{array}$ \\
\hline & $\begin{array}{l}\text { Social Investment Program } \\
\text { "Ukraine - Resident of the } \\
\text { Future" }\end{array}$ & $\begin{array}{l}\text { Grants for the implementation of programs on sustainable environment } \\
\text { development, development of social entrepreneurship. }\end{array}$ \\
\hline $\begin{array}{l}\text { Eastern Partnership Territorial } \\
\text { Cooperation (EaPTC) }\end{array}$ & $\begin{array}{l}\text { Program of border region } \\
\text { sustainable cooperation }\end{array}$ & $\begin{array}{l}\text { Promotion of socio-economic development. Focused on: improving } \\
\text { living conditions of local communities in target transboundary regions } \\
\text { through joint projects of socio-economic development; development } \\
\text { and implementation of common solutions to common problems } \\
\text { relevant to neighbouring regions. }\end{array}$ \\
\hline $\begin{array}{l}\text { European Bank for } \\
\text { Reconstruction and } \\
\text { Development }\end{array}$ & $\begin{array}{l}\text { Financial support for } \\
\text { agribusiness }\end{array}$ & $\begin{array}{l}\text { Financing, including long-term loans, replenishment of working capital, } \\
\text { financing of multi-project facilities to meet the changing needs of } \\
\text { agribusiness enterprises. }\end{array}$ \\
\hline Ukraine-Habitat Foundation & $\begin{array}{l}\text { Promotion of small and } \\
\text { medium business development }\end{array}$ & $\begin{array}{l}\text { Development of regions through the small and medium-sized business } \\
\text { development by the implementation of local investment programs } \\
\text { under the guaranty of local authorities. }\end{array}$ \\
\hline Eastern Europe Foundation & $\begin{array}{l}\text { Social and economic } \\
\text { development programs }\end{array}$ & $\begin{array}{l}\text { Advancement of Corporate Social Responsibility, Local Economic } \\
\text { Development, Municipal Partnerships, Business and Economic Education }\end{array}$ \\
\hline
\end{tabular}

Grant assistance for civil and industrial construction projects is an effective alternative to public financing, which also helps identify the most competitive, socially significant and cost-effective projects.

It is proposed to amend the Law of Ukraine "On Investment Activity” regarding clarification of investing in social-cultural and industrial facilities procedure (including production, service, auxiliary) in rural areas. Investments are offered through construction financing funds, real estate funds, joint investment institutions, and bond issues. The use of such methods of funding these objects will enable control over construction process and targeted use of funds; provide a guarantee of investors' rights to receive the planned effect of investments; will have other advantages depending on the chosen mechanism.

Also, within the framework of the legislation and regulations on investing in the development of rural area housing construction and in order to intensify countryside housing construction as individual developers and business entities, it is proposed to create mutual funds for financing of housing construction and its arrangement in the countryside. Such funds are expedient to form at the expense of voluntary contributions of their participants - individual developers within one or several (nearby) rural settlements. Management of such a fund is proposed to be put on authorized members elected at the general meeting of participants.

At the expense of regular contributions and fund investment activity, the amount of financial resources will be formed, which will subsequently be issued to its participants for the construction of residential objects, economic structures, their repair, reconstruction, arrangement, etc. If the developer - fund participant needs an amount of funds exceeding his contributions, then at the expense of accumulated funds he will be able to receive the required amount. Subsequently, such a developer will have to return the "surplus" of funds in the term provided by the contract. It is proposed to allow members of the fund receive funds for construction on a non-interest basis, which is one of the main advantages of such a fund in comparison with bank loans.

It is assumed that such a fund will help individual developers obtain government grants, compensation for loans, defined by the Law of Ukraine "On Priority of Village and Agro-Industrial Complex Social Development in National Economy." Such assistance 


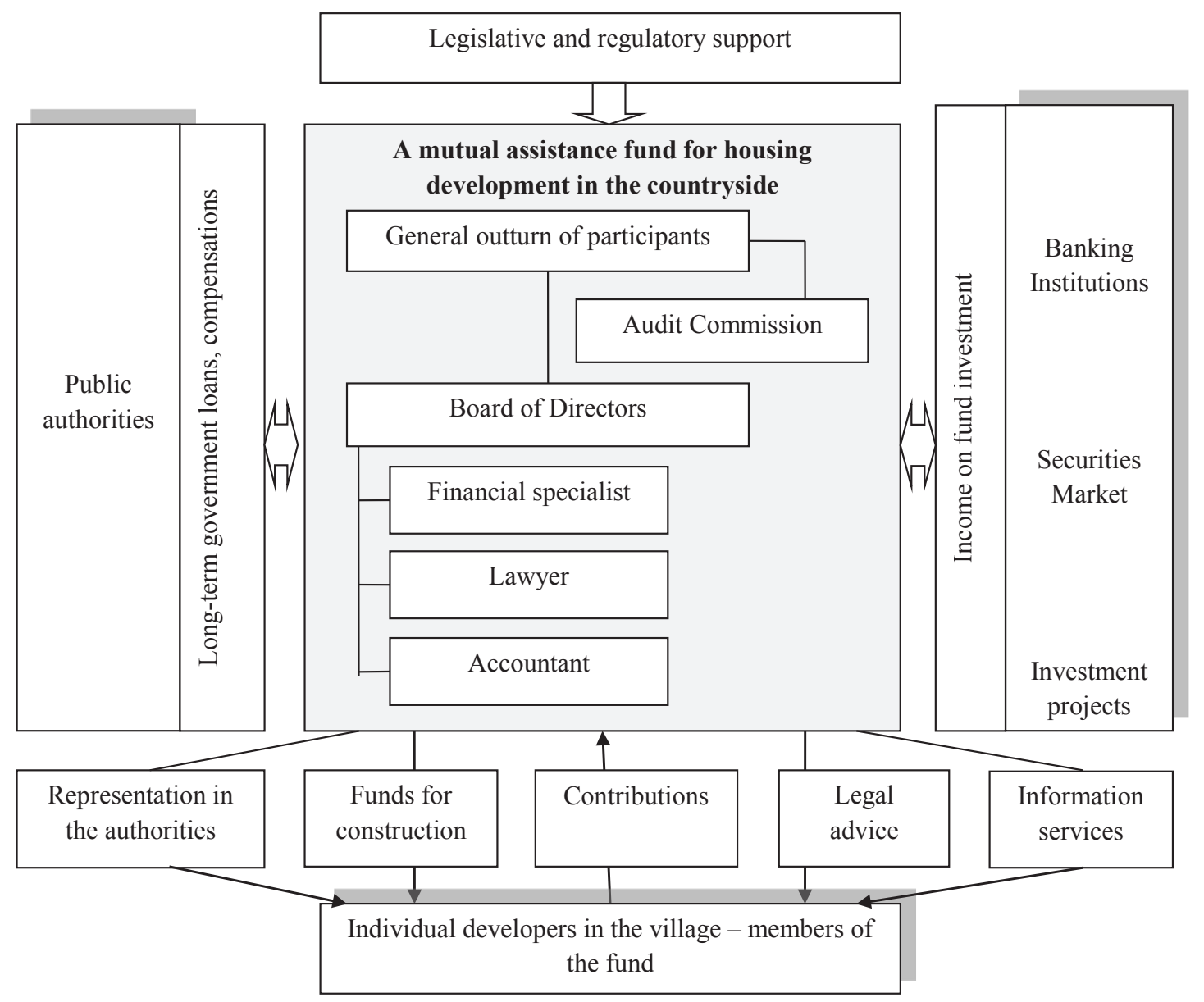

Figure 1. The operation mechanism of mutual assistance fund of housing development in rural Ukraine

will be provided in the form of legal and advisory assistance in the preparation and submission of the necessary documentation to the appropriate authorities for obtaining appropriate benefits and loans. In order to perform such functions, it is proposed to involve a lawyer who will provide relevant services as a part of the fund, as well as take part in drawing up contracts on issuing funds for construction to participants - Figure 1.

Another measure to promote the development of housing construction in rural areas is the financing of funds by enterprises as an element of motivation and stimulation of labour for repair, reconstruction of residential buildings and household facilities. This form of provision of targeted funds will enable workers of enterprises living in rural areas to work on improving their living conditions, housing facilities. For enterprises, this form of motivation will have a longterm effect, ensuring the formation of a positive attitude of employees to the company and increasing the degree of their residence in the area.

Modern economic, legal, and political conditions in the state create opportunities for the formation of such a financing source for housing construction as preferential loans, targeted financing from local budgets. To accomplish this, decentralization of power is important, which will enable to accumulate funds for the implementation of rural areas' balanced development programs on the ground, the creation of proper living conditions in the countryside.

\section{Conclusions}

Investigating the formation and development of investment sources for industrial and civil construction, the following generalizations are made. During research period, investment in industrial and civil engineering is uneven and marked by a significant dependence on the general state of the economy. In the general reduction of industrial and civil construction capital investment in the context of the absolute majority of investment sources, there are some structural changes. They manifest themselves in an increase in absolute and relative values of funds invested for housing construction and an increase in enterprises' own funds share in the total cost of capital investment. At the same time, in absolute and relative terms, capital investments are reduced, the sources of which are: state and local budgets, bank loans, funds from foreign investors and other sources of financing. The increase in absolute and relative values 
of funds invested for housing construction and increase in own funds share of enterprises and organizations in the total value of capital investments is the result of an objective process of establishing market principles in the country's economy, according to which business entities in their production and economic and market activity should rely primarily on their own resource potential and profitability. To increase investment in countryside industrial and civil construction as a factor in increasing socio-economic and environmental impact of the agrarian sector, it is advisable to use different sources of capital investment and increase their number.
An attractive investment environment for countryside industrial and civil construction is formed at the expense of: sustainable development of economy and society; encouragement of entrepreneurial activity of population; encouraging enterprises and organizations to carry out expanded reproduction; competent banking and financial and credit policy of the state and local self-government bodies.

Further research will be directed towards the formation of proposals on improving state regulation mechanisms of construction development in the northern territories of Ukraine.

\section{References:}

Vasyliev, O. V. (2010). Modern forms of investment in housing construction. Communal economy of cities: scientific and technical collection, 92, 75-79.

Safonov, Yu. M., Yevtieieva, V. H. (2013). About mechanisms of attraction and sources of financing of investments in housing construction in Ukraine. Investments: practice and experience, 16, 18-21.

Rybak, A. I., Azarova, I. B. (2014). Analysis of the mechanisms of financing construction projects in the field of housing construction. Market mechanism of financing. Management of complex systems development, 18, 88-97.

Kamiński, R. (2017). Investment in social infrastructure in rural areas - does it support the development of social capital? Retrieved from: https://ageconsearch.umn.edu/record/139080/files/vol.\%207_6.pdf?version=1

Chen, C., Ao, Y., Wang, Y., Li, J. (2018). Performance appraisal method for rural infrastructure construction based on public satisfaction. PLoS ONE 13(10): e0204563. Retrieved from: https://doi.org/10.1371/journal. pone.0204563

Order of the State Statistics Committee of Ukraine «On approval of the methodology for calculating the index of capital investments ». (n.d.). Retrieved from: http://www.uapravo.net/akty/law-osnovni/akt5duoy2u.htm

Yongheng, D., Jing, W. (2014). Economic returns to residential green building investment: The developers' perspective. Regional Science and Urban Economics, 47, 35-44.

Azhaman, I. A. (2014). Investing in the development of industrial construction in rural Ukraine. Agrosvit, 16, 23-27.

Azhaman, I. A. (2014). Investment provision of housing development in rural areas. Investments: practice and experience, 16, 28-33.

Website of the European Information and Research Center: European experience of legislative regulation of state support and development of rural settlements. Retrieved from: http://euinfocenter.rada.gov.ua/uploads/ documents $28937 . p d f$

Website of the Embassy of Japan in Ukraine: "The Kusanone Program". Retrieved from: http://www.ua.emb-japan.go.jp/ jpn/bi_ua/oda/humansec/info_r.pdf

Website: Territorial Cooperation of the Eastern Partnership Countries (EaPTC). Retrieved from: http://eaptc.eu/ $\mathrm{ru}$ /eaptc-program.html

Report on the results of the project "Investment Policy in Agriculture: Ukraine". Retrieved from: http://www.oecd.org/ globalrelations/Agricultural_Investment_Policies_Ukraine_UKR.pdf

Decree of the Cabinet of Ministers of Ukraine $\ll$ On approval of the Rules for the provision of long-term loans to individual developers of housing in the village». (n.d.). Retrieved from: http://zakon2.rada.gov.ua/laws/ show/1597-98-p 